\title{
Infliximab in the treatment of refractory uveitis. Does dose really matter?
}

\author{
MD Sukesh Sukumaran*, MD Katherine Marzan, MD Andreas Reiff \\ From 18th Pediatric Rheumatology European Society (PReS) Congress \\ Bruges, Belgium. 14-18 September 2011
}

\section{Background}

Infliximab has been shown to be beneficial in treating pediatric uveitis. No data exist on optimal dosing and true efficacy of higher dosing.

\section{Objectives}

To compare the efficacy of low dose (LD) infliximab $(<10 \mathrm{mg} / \mathrm{kg})$, moderate dose (MD) infliximab $(\geq 10-15 \mathrm{mg} /$ $\mathrm{kg})$ and high dose (HD) $(\geq 15-20 \mathrm{mg} / \mathrm{kg})$ in the treatment of various forms of uveitis.

\section{Methods}

We conducted a retrospective study at Children's Hospital Los Angeles and Miller Children's Hospital, Los Angeles. We performed comprehensive medical record review to identify demographic information and clinical data. Ocular outcome was assessed by anterior chamber cell density, flare, visual acuity, intra ocular pressure and ability to reduce or stop concomitant topical or systemic steroids.

\section{Results}

The mean age of patients was 11.2 years and mean duration of uveitis was 33 months. All patients had bilateral eye disease. $71 \%$ of children had preexisting complications including glaucoma and cataracts. Of the 34 patients, there were 6 (18\%), 19 (56\%) and 9 (26\%) patients in LD, MD and HD group respectively.

Characteristics, duration of uveitis and response to therapy are described (Table 1).

Table 1

\begin{tabular}{llll}
\hline & LD & MD & HD \\
\hline Anatomic classification of Uveitis among cohort (\%) & & 100 & 33 \\
\hline Anterior Uveitis & 0 & $<1$ & 1 \\
\hline Intermediate Uveitis & 0 & 26 & 33 \\
\hline Posterior Uveitis & 0 & 42 & 44 \\
\hline Panuveitis & 8.9 & 8.4 & 10.5 \\
\hline Mean age at diagnosis of uveitis (yrs) & 10.8 & 12.1 \\
\hline Mean age of onset of treatment (yrs) & 2.0 & 3.5 \\
\hline Mean duration of other medication regimens prior to infliximab (yrs) & 10.6 & 15.6 \\
\hline Duration of treatment with topical steroids prior to infliximab (mo) & 3.1 & 12.3 & 10.2 \\
\hline Time to discontinuation of steroids after infliximab (mo) & 67 & 9.5 \\
\hline Patients requiring dose escalation (\%) & 35 & 55 \\
\hline Average time to dose escalation (mo) & 5.1 & 7.5 \\
\hline
\end{tabular}




\section{Conclusion}

We found that treatment with infliximab is beneficial and that dose escalation up to 4 times above the approved dose is often necessary to achieve disease control. LD infliximab was found not to be sufficient in disease control. Although we found MD to be effective, one third of patients in this group required escalation for better disease control. Despite escalated doses, treatment appeared safe in the short term and no adverse events were observed.

Published: 14 September 2011

doi:10.1186/1546-0096-9-S1-P219

Cite this article as: Sukumaran et al:: Infliximab in the treatment of refractory uveitis. Does dose really matter? Pediatric Rheumatology 2011 9(Suppl 1):P219.

Submit your next manuscript to BioMed Central and take full advantage of:

- Convenient online submission

- Thorough peer review

- No space constraints or color figure charges

- Immediate publication on acceptance

- Inclusion in PubMed, CAS, Scopus and Google Scholar

- Research which is freely available for redistribution

Submit your manuscript at www.biomedcentral.com/submit 